\title{
Pielęgniarstwo jako zawód zaufania publicznego w opinii pacjentów
}

\author{
Nursing as a profession of public trust in the opinion of patients
}

\section{Streszczenie}

Wstęp. Pielęgniarstwo $\mathrm{w}$ ujęciu teoretycznym jest profesją o wyjątkowym charakterze oraz misją związaną z opieką nad pacjentem. W ujęciu praktycznym stanowi bardzo odpowiedzialną, stresującą i ciężką pracę. W ostatnich latach pielęgniarstwo przeszło liczne reformy, które wpłynęły na obecną autonomię zawodu. Obecnie stanowi integralną część systemu opieki zdrowotnej w Polsce.

Cel. Celem pracy jest zbadanie opinii pacjentów na temat pielęgniarstwa jako zawodu zaufania publicznego na podstawie ich oceny pielęgniarek/pielęgniarzy jako osób godnych zaufania oraz ustalenie wpływ czynników socjodemograficznych na te opinie.

Materiał i metody. Badania przeprowadzono w Wojewódzkim Szpitalu Zespolonym w Toruniu oraz Podstawowej Opiece Zdrowotnej w Toruniu. W badaniach dobrowolnie uczestniczyło 107 dorosłych pacjentów. Badania przeprowadzono metodą szacowania i metodą sondażu diagnostycznego. Jako narzędzie badawcze posłużył kwestionariusz ankiety własnego autorstwa. wykorzystany po wcześniejszym uzyskaniu zgody dyrekcji obu placówek oraz Komisji Bioetycznej.

Wyniki. Na podstawie analizy uzyskanych wyników można wywnioskować, iż wśród respondentów nie ma ani jednej osoby, która nie darzyłaby pielęgniarek zaufaniem. Dodatkowo wynika, że mężczyźni w większym stopniu niż kobiety uważają pielęgniarkę/pielęgniarza za osobę godną zaufania. Najwięcej osób z deklaracją „raczej tak” znajduje się w grupie 31-50 lat, co stanowi 42,9\% badanych. Analizując ilość udzielonych odpowiedzi „raczej tak”, można wysunąć wnioski, iż liczba respondentów opowiadających się za tym stwierdzeniem rośnie wraz ze wzrostem poziomu wykształcenia. Uzyskane dane są dowodem na to, iż ankietowani z miast uważają pielęgniarkę/pielęgniarza za osoby godne zaufania $\mathrm{w}$ większym stopniu niż pacjenci ze wsi.

Wnioski. 1. Opinie społeczeństwa na temat personelu pielęgniarskiego są pozytywne. 2. Czynniki socjometryczne mają słaby wpływ na poziom zaufania do zawodu pielęgniarki.

\footnotetext{
Abstract

Introduction. Nursing in theoretical terms is a profession with a unique character and mission related to patient care. In practical terms it is very responsible, stressful and hard work. In recent years, nursing underwent numerous reforms that affect the current autonomy of the profession. Currently, it is an integral part of the health care system in Poland.
} 
Aim. The aim of the study is to examine patients' views about nursing as a profession of public trust on the basis of their evaluation of nurses/male nurses as people worthy of confidence and determination of the impact of socio-demographic factors on these opinions.

Material and methods. The study was conducted at the Regional Hospital in Torun and Primary Health Care in Torun. In the study there voluntarily participated 107 adult patients. The research was carried out by means of estimating method and a diagnostic survey. As a research tool our own questionnaire applied after obtaining. the prior consent from the management of both institutions as well as from the Bioethics Committee.

Results. Based on the analysis of the results it can be concluded that among the respondents there is not one person who does not trust nurses. Additionally it shows that men more than women believe the nurse / nurse for a trustworthy person. Most people with the declaration "rather yes" is in the group of 31-50 years, which is $42.9 \%$ of the respondents. Analyzing the number of answers "rather yes", you can eject the conclusion that the number of respondents opting for this statement increases with the level of education. The data obtained are proof of the fact that respondents from the cities believe the nurse / nurse as a person worthy of trust to a greater extent than those from the countryside.

Conclusions. 1. Public opinions on the nursing staff are positive. 2. Socio-demographic factors have a weak impact on the level of trust to the nursing profession.

Słowa kluczowe: pielęgniarstwo, zawód zaufania publicznego, pacjent

Key words: nursing, the profession of public trust, the patient

\section{Wstęp}

Pielęgniarstwo jest zawodem o szczególnej misji związanej ze sprawowaniem opieki nad pacjentem.

Współcześnie wyniki badań naukowych pozwalają pielęgniarce na realizację świadczeń zawodowych opartych na wiedzy sprawdzonej empirycznie. Umożliwiają również wykorzystanie najnowszych rozwiązań w zakresie nauk o zdrowiu w dążeniu do najwyższej jakości świadczonych usług. Gwarantuje to działania właściwe, efektywne i w najwyższym stopniu korzystne dla pacjenta. Ogranicza się w ten sposób lub eliminuje rozwiązania niewłaściwe, poprawiając tym samym jakość opieki pielęgniarskiej. Minimalizuje się również niepotrzebne koszty, dzięki czemu działania pielęgniarki stają się zgodne $\mathrm{z}$ aktualnie szeroko stosowaną polityką ograniczania kosztów w zakładach opieki zdrowotnej [1].

Pielęgniarstwo to profesja stanowiąca integralną część systemu ochrony zdrowia w Polsce. W ostatnich dekadach wzmocniła się pozycja zawodu i zwiększył zakres autonomii pielęgniarki. Przepisy prawne jasno zdefiniowały zakres jej kompetencji oraz samodzielności. Niestety dotychczasowe przeobrażenia systemu ochrony zdrowia utrwaliły negatywny wizerunek świadczeń opieki zdrowotnej. Wzrósł także poziom oczekiwań pacjentów wobec świadczeniodawców, w tym również w odniesieniu do pielęgniarek. Aktualnie bowiem pacjent jest aktywnym uczestnikiem rynku usług zdrowotnych oraz świadomym, w zakresie swoich praw i oczekiwań, biorcą świadczeń w systemie. Uzasadniona jest zatem pod każdym względem dbałość o jego opinie.

Termin zawód zaufania społecznego możemy odnaleźć w art. 17 Konstytucji Rzeczypospolitej Polskiej z dnia 2 kwietnia 1997 r. Artykuł ten wiąże wykonywanie zawodu zaufania publicznego z istnieniem samorządu zawodowego. Do zawodów zaufania publicznego zalicza się profesje, których przedstawiciele wykonują zadania o szczególnym charakterze z punktu widzenia troski o realizację interesu publicznego [2]. Trybunał Konstytucyjny w orzeczeniu z 7 maja 2002 r. określa zawód zaufania publicznego, jako „polegający na obsłudze 
osobistych potrzeb ludzkich, wiążący się z przyjmowaniem informacji dotyczących życia osobistego i zorganizowany w sposób uzasadniający przekonanie społeczne o właściwym dla interesów jednostki wykorzystywaniu tych informacji przez świadczących usługi. Wykonywanie zawodu zaufania publicznego określane jest dodatkowo normami etyki zawodowej, szczególną treścią ślubowania, tradycją korporacji zawodowej czy szczególnym charakterem wykształcenia wyższego i uzyskanej specjalizacji" [2]. Obecnie w polskim systemie prawnym obowiązują regulacje ustawowe powołujące samorządy zawodowe zawodów zaufania publicznego [3].

Centrum Badania Opinii Społecznej w Polsce prowadzi między innymi badania nad opinią społeczną dotyczące zawodów zaufania społecznego. Odpowiedzi ankietowanych dowodzą, iż zawód zaufania publicznego kojarzy się polskiemu społeczeństwu z profesjami wymagającymi od osób, które podejmują się jego wykonywania specjalnych standardów etycznych, moralnych i wysokiej jakości usług. Działania przedstawicieli takich zawodów wiążą się z ochroną życia, zdrowia, wolności i godności ludzkiej, dlatego ich znaczenie dla społeczeństwa jest szczególne [4]. Polskie pielęgniarki mają duże poparcie społeczeństwa wynoszące aż 88\% i w rankingu 26 zawodów zawodów zaufania społecznego zajmują drugie miejsce [5]. Osobom związanym z takimi profesjami społeczeństwo często powierza informacje na temat swego życia prywatnego, które stanowią tajemnicę zawodową.

Należy podkreślić także pozycję zawodową pielęgniarek, którym zgodnie z art. 24 Ustawy o zawodach pielęgniarki i położnej przysługuje ochrona prawna przewidziana dla funkcjonariuszy publicznych [4].

Celem pracy jest zbadanie opinii na temat pielęgniarstwa jako zawodu zaufania publicznego na podstawie oceny pielęgniarek/pielęgniarzy przez pacjentów oraz ustalenie wpływ czynników socjodemograficznych na te opinie.

\section{Materiał i metody}

Badania przeprowadzono w okresie od września 2015 do marca 2016 roku wśród 107 dorosłych pacjentów oddziałów Wojewódzkiego Szpitala Zespolonego oraz placówki podstawowej opieki zdrowotnej (POZ) w Toruniu. Badani zostali poinformowani, że udział w badaniu jest dobrowolny. Oddziały szpitalne oraz przychodnię POZ, których pacjenci zostali poddani badaniu, wybrano losowo. W badaniach zastosowano metodę sondażu diagnostycznego. Narzędzie badawcze stanowił autorski kwestionariusz ankiety wykorzystany po wcześniejszym uzyskaniu zgody pacjentów, dyrekcji obu placówek oraz Komisji Bioetycznej.

Analizę statystyczną wyników badań wykonano przy użyciu programu Microsoft Office Excel 2007 z zastosowaniem testu chi kwadrat $\left(\chi^{2}\right)$ dla zbadania zależności pomiędzy dwiema zmiennymi nominalnymi oraz określono współczynnik korelacji Spearmana. Przyjęto dla wszystkich analiz współczynnik istotności na poziomie $\mathrm{p} \leq 0,05$.

\section{Wyniki}

Ponad połowę ankietowanych (53,3\%) stanowiły kobiety. Najliczniejszą grupą byli respondenci w wieku 31-50 lat (43,9\% badanych). Wśród badanych dominowały osoby z wykształceniem średnim (43,9\%) a najmniej liczną grupę stanowiły osoby $\mathrm{z}$ wykształceniem podstawowym/gimnazjalnym (4 osoby - 3,7\% badanych). Respondenci najczęściej mieszkali w mieście $(67,3 \%)$ a mieszkańcami wsi było $32,7 \%$ pacjentów.

Udzielając odpowiedzi na pytanie dotyczące tego, czy pielęgniarka/pielęgniarz jest osobą godną zaufania respondenci mogli wskazać jeden z czterech wariantów: „nie”, „raczej nie”, „raczej tak”, „tak”. 
Wyniki badań wskazują na słabą i nikłą korelację między wiekiem, płcią, wykształceniem i miejscem zamieszkania badanych a prezentowaną przez nich opinią na temat poziomu zaufania wobec grupy zawodowej pielęgniarek/ pielęgniarzy.

Niezależnie od płci respondentów żaden z nich nie wybrał odpowiedzi negatywnej, świadczącej o zupełnym braku zaufania wobec pielęgniarek/pielęgniarzy. Odpowiedź „raczej nie" wybrało więcej kobiet $(66,7 \%)$ niż mężczyzn $(33,3 \%)$. Natomiast raczej ufa grupie zawodowej 51,4\% mężczyzn i 48,6\% kobiet. Wśród pacjentów deklarujących swoje pełne zaufanie do pielęgniarek i pielęgniarzy było 43,5\% kobiet i 56,5\% mężczyzn.

Raczej nie ufa pielęgniarkom/pielęgniarzom tylko 3 badanych w wieku 31-50 lat. Częściowe zaufanie do grupy zawodowej prezentowali respondenci z grupy wiekowej 31-50 lat $(42,9 \%)$ oraz 18-30 lat (28,6\%). W dalszej kolejności osoby w wieku 51-70 lat (20,0\%), powyżej 90 lat (5,7\%) oraz 71-90 lat (2,9\%). Częściej pełne zaufanie deklarowało 42,0\% respondentów w wieku 31-50 lat oraz 51-70 lat (36,2\%), w porównaniu do badanych z kategorii wiekowej 1830 lat $(15,9 \%)$ i $71-90$ lat $(5,8 \%)$.

Raczej nie ufa pielęgniarkom/pielęgniarzom 66,7\% badanych z wykształceniem wyższym i tylko 1 pacjent z wykształceniem średnim (33,3\%). Takiej odpowiedzi nie udzielił żaden $\mathrm{z}$ respondentów $\mathrm{z}$ wykształceniem zawodowym i podstawowym. Częściowe zaufanie deklarowało 40\% badanych z wykształceniem wyższym i 37,1\% absolwentów szkół średnich oraz 17,1\% pacjentów legitymujących się ukończeniem szkoły zawodowej i 5,7\% osób, które ukończyły tylko szkołę podstawową/gimnazjum. Natomiast pełne zaufanie wskazało 47,8\% badanych ze średnim wykształceniem i 29,0\% absolwentów szkół wyższych oraz 20,3\% respondentów legitymujących się wyksztalceniem zawodowym i 2,9\% osób, które ukończyły szkołę podstawową/gimnazjum.

Raczej nie darzy zaufaniem grupy pielęgniarek i pielęgniarzy 66,7\% mieszkańców miast i 33,3\% osób, które mieszkają na wsi. Częściowe zaufanie prezentuje 77,1\% respondentów z miasta i $22,9 \%$ ze wsi. Natomiast pełne zaufanie wskazało 62,3\% mieszkańców miast i 37,7\% osób pochodzących ze wsi.

\section{Dyskusja}

Przeprowadzenie badań własnych oraz analiza pytania o opinie pacjentów na temat pielęgniarek/pielęgniarzy jako osób godnych zaufania pozwoliły ocenić $\mathrm{w}$ jakim stopniu czynniki socjodemograficzne wpływają na postrzeganie pielęgniarstwa jako zawodu zaufania publicznego.

Marcinowicz i współautorzy ustalili zależność między zadowoleniem pacjentów z opieki i wpływem czynników socjodemograficznych [6]. W aktualnych badaniach wprawdzie współczynnik korelacji Spearmana potwierdził tę zależność, ale wykazał słabe powiązanie. W badaniach Brodzińskiej nie ustalono takiej zależności. Badania Kozimali wykazały, iż zależność pomiędzy wpływem czynników socjodemograficznych jak: wiek, płeć oraz poziom wykształcenia respondentów na doświadczenia pacjentów nie jest istotna statystycznie [7]. Brak statystycznie znamiennej zależności w ocenie opieki pielęgniarskiej autorka tłumaczy małą liczbą osób z wykształceniem wyższym oraz małą liczebnością osób w przedziale wiekowym 2130 lat uczestniczących w badaniu.

Badania Kojder i Zarzyckiej dowodzą, iż pozytywniej oceniają pielęgniarki pacjenci mający z nią osobisty kontakt niż te osoby, które nie korzystają z jej usług [8]. Podobnie twierdzą Leszczyńska i współautorzy, badający opinie pacjentów na temat pielęgniarek środowiskowych. Wykazali oni, że bardzo wyraźną zależność pomiędzy częstością wizyt pielęgniarki, a łączną oceną jakości jej usług ( $p=0,00001)$ [9]. 
Obecność pielęgniarek w grupie zawodów zaufania społecznego w Polsce potwierdza profesjonalizm tej grupy zawodowej, wysoką jakość usług, bezpośrednią służbę ludziom oraz działalność w interesie społecznym[3]. Badania prowadzone przez CBOS w 2004 roku dotyczące opinii na temat zawodów zaufania publicznego wskazują na uznanie dla pozycji pielęgniarek przez 88\% respondentów. Wyżej notowani byli tylko lekarze (poparcie 94\% badanych) [5]. W badaniach nad uczciwością i rzetelnością zawodową (CBOS 2006), które niewątpliwie wiążą się z zaufaniem pielęgniarki znalazły się na bardzo wysokim drugim miejscu z $60 \%$ poparciem respondentów. Należy dodać, że na pierwszym miejscu znaleźli się przedstawiciele świata nauki.

Na amerykańskiej liście „The Gallup Poll”, pielęgniarki od kilku lat (czyli od momentu kiedy zostały na niej uwzględnione) zajmują pierwszą pozycję [10].

Badaniem poziomu zaufania społecznego zajmowały się również Skorupska i Machowicz [11]. Wśród dziesięciu zaproponowanych profesji pielęgniarki zajęły najwyższą pozycję. Potwierdzeniem tych deklaracji może być fakt, iż aż 85, 8\% ankietowanych, mając do wyboru różnych świadczeniodawców usług opiekuńczych to właśnie pielęgniarce powierzyłoby opiekę nad najbliższą osobą. W badaniach Mędrzyckiej - Dąbrowskiej w pytaniu dotyczącym wizerunku zawodu pielęgniarki w społeczeństwie połowa badanych (50,8\% kobiet i 46,2\% mężczyzn) była zdania, iż pielęgniarstwo jest zawodem cieszącym się dużym zaufaniem i szacunkiem społecznym [12]. Analiza wyników badań własnych także dowodzi, iż żaden respondentów nie wyraził zupełnego braku zaufania wobec pielęgniarki.

Odmienne wyniki w badaniach uzyskały Grabska i Stefańska, w których 76\% respondentów deklarowało zaufanie do pielęgniarek, a 16\% było przeciwnego zdania. Pozostali pacjenci stanowiący $8 \%$ nie potrafili określić swego zdania w tej kwestii. Mroczek i współautorzy badając wizerunek społeczny zawodu pielęgniarki doszli do wniosku, iż respondenci uplasowali ten zawód pod względem zaufania dopiero na czwartym miejscu (opinie $31 \%$ ankietowanych), darząc największym zaufaniem lekarzy (57\%) [12]. Podobne zdanie ankietowani wyrazili podczas badań Jończyk. Negatywne opinie dotyczyły zaufania do sposobów sprawowania opieki pielęgniarskiej [14].

Przyjmuje się, że szacunek wobec zawodów i ich hierarchia stanowi odzwierciedlenie stratyfikacji społecznej oraz statusu społecznego osób zajmujących się daną profesją. W przypadku zawodów medycznych, a zwłaszcza pielęgniarstwa może być czynnikiem wpływającym na relacje z pacjentem i jego zachowania wobec personelu.

\section{Wnioski}

1. Opinie społeczeństwa na temat personelu pielęgniarskiego są pozytywne.

2. Czynniki socjometryczne mają słaby wpływ na poziom zaufania do zawodu pielęgniarki.

\section{Zalecenia dla praktyki pielęgniarskiej}

Opinia pacjentów na temat postrzegania pielęgniarstwa stanowi integralną część oceny zawodu jako profesji zaufania publicznego. Wnikliwa analiza składowych może przełożyć się na poprawę postrzegania zawodu pielęgniarki/pielęgniarza. Niepochlebne skojarzenia i opinie zwłaszcza wśród młodych osób mogą przyczynić się do zwiększania niedoborów personelu. Analizowanie badań tego typu może wpływać na poprawę wizerunku polskiej pielęgniarki, a tym samym na promocję zawodu. 


\section{Bibliografia / Bibliography:}

1. Łukasz-Paluch K., Franek G. A. Ruch zawodowy i przemiany w kształceniu podstawowym pielęgniarek na przełomie wieków. Problemy Pielęgniarstwa. 2008; 16(1,2): 173-180.

2. Wojtczak K. Reglamentacja form wykonywania zawodów zaufania publicznego w rozwiązaniach prawa polskiego państw Unii Europejskiej. [w:] Zawody zaufania publicznego a interes publiczny - korporacyjna reglamentacja versus wolność wykonywania zawodu. Dział Wydawniczy Kancelarii Senatu. Warszawa 2002.

3. Krasnowolski A. Zawody zaufania publicznego, zawody regulowane oraz wolne zawody. Geneza, funkcjonowanie i aktualne problemy. [w:] Opracowania tematyczne OT-625. Kancelaria Senatu. Biuro Analiz i Dokumentacji. Warszawa 2013.

4. Skowroński A. W interesie obywateli i publicznym. Magazyn Pielęgniarki i Położnej. 2009;1-2:6-7.

5. Badora B., Roguska B. Opinia społeczna na temat zawodów zaufania publicznego. [w:] Komunikat z badań CBOS. Warszawa 2004.

6. Marcinowicz L., Borzuchowska A., Grębowski R, Rybaczuk M. Wybrane elementy jakości usług pielęgniarek i położnych rodzinnych w ocenie pacjentów. Cz. II. Zadowolenie pacjentów z pielęgniarki i położnej rodzinnej. Zdrowie Publiczne. 2002;112(1):69-72.

7. Kozimala M., Putowski L. Ocena satysfakcji pacjentów z opieki pielęgniarskiej w Centrum Opieki Medycznej w Jarosławiu. Annales Academiae Medicae Silesiensis. 2009;63(1):20-27.

8. Kojder E., Zarzycka D. Wizerunek zawodowy pielęgniarki i jego determinanty. Pielęgniarstwo XXI wieku. 2014;2(47):47-52.

9. Leszczyńska M., Krajewska-Kułak E., Łukaszuk C., Sobolewski M., Kędziora-Kornatowska K., Borzuchowska A. Opinia pacjentów o jakości usług podstawowej opieki zdrowotnej na terenie miasta Jasła i jego okolic. Probl. Hig. Epidemiolog. 2007;88(3):277-285.

10. Derczyński W. O uczciwości i rzetelności zawodowej. [w:] Komunikat z badań CBOS. Warszawa 2006.

11. Skorupska A., Machowicz A. Wybrane aspekty postaw pracowników ochrony zdrowia wobec pielęgniarek. Problemy Pielęgniarstwa. 2010;18(1):53-59.

12. Mędrzycka-Dąbrowska W., Bąkowska G., Kwiecień-Jaguś K., Gaworska-Krzemińska A. Postrzeganie zawodu pielęgniarki przez młodzież szkół ponadgimnazjalnych jako wybór przyszłego zawodu doniesienia wstępne. Problemy Pielęgniarstwa. 2012;20(2):192-200.

13. Mroczek B., Parakiewicz A., Grochans E. i wsp. Wizerunek społeczny zawodu pielęgniarki. Fam. Med. Prim. Care Rev. 2012;14(1):4-47.

14. Jończyk J. Ocena satysfakcji pacjenta w kontekście jakości opieki zdrowotnej. Prace naukowe Uniwersytetu Ekonomicznego we Wrocławiu. 2011;155:301-310. 